\title{
Plovdivská slavistika v minulém roce oslavila kulaté jubileum (Paisijova čtení 2018)
}

\author{
Jakub Mikulecký (Praha)
}

Ve dnech 8. až 10. 11. 2018 se v bulharském Plovdivu uskutečnila jubilejní mezinárodní vědecká konference Paisijova čteni. Plovdivská filologie si na konferenci připomněla 45 let své existence a slavnostní ráz měla také tradičně hojně navštěvovaná sekce slavistiky, která na konferenci oslavila 40 let své plovdivské existence. Od té doby Plovdivská univerzita udělila diplomy celkem 576 absolventům v oboru slovanské filologie celkem ve třech profilech - bohemistika (243), polonistika (196) a konečně v nejmladším srbském a chorvatském profilu (139). Jubilejní Paisijova čteni v roce 2018 měla nadstandardně vysokou zahraniční účast. Na konferenci vystoupilo úhrnem 232 odborníků z celkem 39 univerzit a vědeckých pracovišti z celkem 13 zemí (Bulharsko, Česká republika, Polsko, Rusko, Bělorusko, Bosna a Hercegovina, Srbsko, Chorvatsko, Mad’arsko, Řecko, Turecko, Francie a Španělsko).

Jedním z témat jubilejní slavistické sekce bylo padesáté výročí od bouřlivých událostí roku 1968 v širší (nejen československé) perspektivě. Saša Šmulja ve svém referátu O 1968. години у српској кюижевности nastínil koncept zamýšleného článku na téma červnových událostí v bývalé Jugoslávii s důrazem na jejich recepci v tehdejší jugoslávské literatuře. Mieczysław Balowski ve svém příspěvku Jezyk czeskich wydarzeń roku 1968 podrobně analyzoval lexikum českého periodického tisku během okupace Československa, přičemž dospěl k zajímavým sociolingvistickým konkluzím. Na téma se zaměřil i autor této zprávy, jeho referát Připoutaný balón a Andilek aneb panna z Bambergu. Filmová tvorba Binky Željazkovové a Marrana Gosova v československé recepci na pozadi pražského jara 1968 měl ambici poukázat prostřednictvím dvou historických sond na některé proměny české a slovenské filmové publicistiky ve vztahu $\mathrm{k}$ osmašedesáté- mu. S důsledky vojenského potlačení pražského jara a následné normalizace se tematicky pojil také referát Jaroslava Otčenáška Česká slavistická folkloristika 1968-1989. Problémy - ztráty - nové směry, ve kterém autor podrobně analyzoval úskalí, s jakými se česká folkloristika musela během normalizační totality vypořádat, poukázal také na nové tendence tohoto oboru po listopadu 1989. Na téma literatury v sepětí komunistické ideologie a moci narazila také Martina Salhiová ve svém příspěvku o pohádkové tvorbě Karla Šiktance (Karel Šiktanc's Fairy Tales before and after 1989). Vladimír Křivánek pro změnu představil nové pohledy na nonkonformní podstatu máchovské tradice (Paradoxes of the Mácha Tradition).

Velmi perspektivním tématem souvisejícím s genezí národních literatur uvnitř totalitních struktur se jevil referát Adriany Kovačevové $\mathrm{Ho}$ motextuality In Translation: A Case Study Of Polish-Bulgarian Literary Contacts Under Communist Regime, a to kromě problematiky homotextuality zejména s ohledem na kontaktologické aspekty zaměřené na vztahy dvou národních literatur v totalitním kontextu. O literární problematice genderu poreferovala z nových perspektiv i Alena Zachová (Recepce genderových stereotypů v české literature). Joanna Wójcik se na konferenci zaměřila na fenomén ženského psaní v současné polské poezii, její referát Kobieta - historia - poezja. Kilka uwag o wspótczesnej polskiej poezji kobiet opět vyvolal obecnější zamyšlení nad problematikou ženského psaní a jeho pozici v současném literárněvědném diskurzu.

Problematikou literatury a politické moci se na konferenci zabývali také přispěvatelé zařazení do velmi početné sekce s názvem Literatura - MocImprovizace. Kromě referátů zaměřených na bulharskou literaturu se v této sekci objevila také témata 
bohemistická, z nichž zaujal př́íspěvek Alexandry Alexandrovové Aтентат срещу културата: Милан Книжак и чешката рок поезия от края на 60-те години на $X X$ век, ve kterém se autorka pokusila o uplatnění nových perspektiv v intepretaci poetiky hudebních textů české kontrakultury šedesátých let minulého století. Z bulharistických literárněvědných příspěvků stojí za pozornost především nové čtení literárního díla Emilijana Staneva, jehož antitotalitní interpretační dekonstrukce se ve svém příspěvku Фигури на властта в романите на Ем. Станев zdařile chopila Tatana Ičevska. Novým prizmatem se na problematiku bulharského národního obrození zaměřila Anna Aleksieva. Využila přitom dichotomii oficiální/neoficiální - okrajové, marginální, nekonformní, které bývají spojovány spíše s dějinami literatur dvacátého století. Aleksieva přitom na bulharském příkladu ukázala, že fenomén transgrese dominantních kulturních diskurzů je hybnou silou v genezi každé národní kultury (Норма и трансгресия. Офичиални и субкултурни репрезентачии на Вззраждането). $\mathrm{V}$ této sekci se krom toho objevily také prríspěvky nahlížející některé závažné teoretické otázky týkající se perspektiv humanitních věd. Bogusław Zieliński a Anna Legeżyńska poreferovali o krizi humanitních věd v širších socioekonomických souvislostech (Kryzys humanistyki, spoteczeństwa czy rynku - spojrzenie z polskiej perspektywy). V tomto ohledu bychom neměli opomenout ani příspěvek Aleksandra Mikołajczaka týkající se problematiky posthumanismu a kompatibility budoucího tzv. postčlověka s tradičními humanitními obory (Zwrot ku rzeczom - posthumanizm czy nowa humanistyka?).

Řada zajímavých prríspěvků zazněla také v rámci sekce věnované dějinám a aktuálním otázkám univerzitní a akademické slavistiky. Marcel Černý publiku Paisijových čteni předsta- vil dosud prakticky neznámou osobnost české a bulharské slavistiky, muzikologa a plovdivského rodáka, Georgiho Bakărdžieva, v referátu Mezi slavistikou a muzikologii. Odchovanec plovdivské univerzity Georgi Nikolov Bakărdžiev-Jantarski (1905-1976) a jeho prínos pro studium česko-bulharských kulturnich a hudebnich vztahů. Další příspěvky této sekce byly zaměřeny na problematiku vývoje a na aktuální stav slavistiky na vybraných evropských univerzitách. Rafał Dymczyk nastínil situaci bulharistiky a perspektivy jejích absolventů na Univerzitě Adama Mickiewicze v Poznani (Bulgarian philology on AMU and its alumni). Elena Krejčová představila některé nové koncepce brněnské bulharistiky. Převážně bilanční charakter měl společný referát Željky Čelić a Tetyany Fuderer o stavu záhřebské ukrajinistiky (20 godina ukrajinistike u Zagrebu u usporedbi s akademskim $i$ društvenim položajem ruskoga jezika u Republici Hrvatskoj).

Na loňských plovdivských Paisijových čtenich se objevilo jako už tradičně široké spektrum tematických příspěvků, od těch s vyloženě bilančním a statistickým charakterem, což bylo ovšem částečně dáno bilancujícím zaměřením celé konference v souvislosti s významnými jubilei tamní filologie a slavistiky, až po referáty s výraznější ambicí v oblasti filologických a slavistických bádání. Organizátoři navíc začali konferenční sborníky Научни трудове zveřejňovat na webových stránkách Filologické fakulty ${ }^{1}$, což by do budoucna mělo plovdivskou filologii a tím i slavistiku více otevřít nejen vědeckým a odborným kruhům, nýbrž i širší veřejnosti.

1 Zatím jsou online $\mathrm{k}$ dispozici ročníky sborníku Hayuни трудове z let 2011-2016. Viz https://science.slovo. uni-plovdiv.net.

\section{Mgr. Jakub Mikulecký, Ph.D}

Slovanský ústav AV ČR, v. v. i.

Valentinská 1, 11000 Praha, Česká republika

jakub.mikulecky@abv.bg 